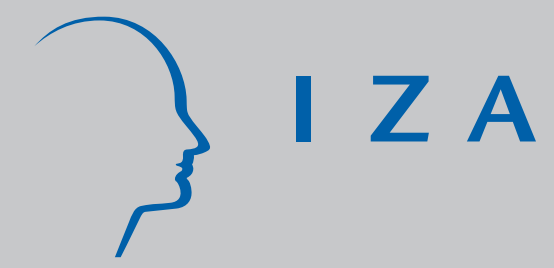

IZA DP No. 1292

Why Are Black-Owned Businesses Less

Successful than White-Owned Businesses?

The Role of Families, Inheritances, and Business Human Capital

Robert W. Fairlie

Alicia M. Robb

September 2004 


\title{
Why Are Black-Owned Businesses Less Successful than White-Owned Businesses? The Role of Families, Inheritances, and Business Human Capital
}

\author{
Robert W. Fairlie \\ University of California, Santa Cruz \\ and IZA Bonn \\ Alicia M. Robb \\ Foundation for Sustainable Development \\ and University of San Francisco \\ Discussion Paper No. 1292 \\ September 2004
}

\author{
IZA \\ P.O. Box 7240 \\ 53072 Bonn \\ Germany \\ Phone: +49-228-3894-0 \\ Fax: +49-228-3894-180 \\ Email: iza@iza.org
}

\begin{abstract}
Any opinions expressed here are those of the author(s) and not those of the institute. Research disseminated by IZA may include views on policy, but the institute itself takes no institutional policy positions.

The Institute for the Study of Labor (IZA) in Bonn is a local and virtual international research center and a place of communication between science, politics and business. IZA is an independent nonprofit company supported by Deutsche Post World Net. The center is associated with the University of Bonn and offers a stimulating research environment through its research networks, research support, and visitors and doctoral programs. IZA engages in (i) original and internationally competitive research in all fields of labor economics, (ii) development of policy concepts, and (iii) dissemination of research results and concepts to the interested public.
\end{abstract}

IZA Discussion Papers often represent preliminary work and are circulated to encourage discussion. Citation of such a paper should account for its provisional character. A revised version may be available directly from the author. 


\title{
ABSTRACT
}

\section{Why Are Black-Owned Businesses Less Successful than White-Owned Businesses? The Role of Families, Inheritances, and Business Human Capital*}

\begin{abstract}
Four decades ago, Nathan Glazer and Daniel Patrick Moynihan made the argument that the black family "was not strong enough to create those extended clans that elsewhere were most helpful for businessmen and professionals." Using data from the confidential and restricted access Characteristics of Business Owners Survey, we investigate this hypothesis by examining whether racial differences in family business backgrounds can explain why black-owned businesses lag substantially behind white-owned businesses in sales, profits, employment size and survival probabilities? Estimates from the CBO indicate that black business owners have a relatively disadvantaged family business background compared with white business owners. Black business owners are much less likely than white business owners to have had a self-employed family member owner prior to starting their business and are less likely to have worked in that family member's business. We do not, however, find sizeable racial differences in inheritances of business. Using a nonlinear decomposition technique, we find that the relatively low probability of having a self-employed family member prior to business startup among blacks does not generally contribute to racial differences in small business outcomes. Instead, the lack of prior work experience in a family business among black business owners, perhaps by limiting their acquisition of general and specific business human capital, negatively affects black business outcomes. We also find that limited opportunities for acquiring specific business human capital through work experience in businesses providing similar goods and services contribute to worse business outcomes among blacks. We compare these estimates to contributions from racial differences in owner's education, startup capital, geographical location and other factors.
\end{abstract}

JEL Classification: J15, J23

Keywords: business outcomes, race, family, self-employment

Corresponding author:

Robert Fairlie

Department of Economics

University of California

Santa Cruz, CA 95064

USA

Email: rfairlie@ucsc.edu

\footnotetext{
* This research was partially funded by the Russell Sage Foundation. Research for this paper was conducted at the Center for Economic Studies at the U.S. Census Bureau. The views expressed here are solely the responsibility of the authors and should not be interpreted as reflecting the views of the Russell Sage Foundation, the U.S. Census Bureau, or the Board of Governors of the Federal Reserve System. We would like to thank Ken Brevoort, Tim Bates, Tom Dunn, John Wolken, and seminar participants at the Winter 2003 Meetings of the American Economic Association, the Board of Governors of the Federal Reserve System, the University of Maryland, the Urban Institute, Baruch College, Yale University and the NBER Workshop on Entrepreneurship for their comments and suggestions. Bill Koch and Garima Vasishtha provided excellent research assistance.
} 


\section{Introduction}

The plight of African-Americans in the labor market is one of the most studied topics by economists, sociologists and other social scientists over the past several decades. Interestingly, however, much less attention has been drawn to the plight of blacks in the main alternative form of making a living -- business ownership. More than 1 out of every 10 working-age adults in the United States owns a business (U.S. Bureau of the Census 1993). Furthermore, the difference between the rate of business ownership among African-Americans and whites is striking. Approximately, 11.6 percent of white workers are self-employed business owners, whereas only 3.8 percent of black workers are self-employed business owners. Several recent studies have examined the causes of the dearth of black-owned businesses and find that relatively low levels of education, assets, and parental self-employment are partly responsible (see Bates 1997, Fairlie 1999, Hout and Rosen 2000, and Robb 2002 for a few recent examples). Although these results are informative, they do not shed light on why black-owned firms lag behind whiteowned firms. For example, Census estimates indicate that black-owned firms have lower revenues and profits, hire fewer employees, and are more likely to close than whiteowned businesses (U.S. Department of Commerce 1997).

The relative lack of success of black-owned businesses in the United States is a major concern among policymakers. It is particularly troubling because business ownership has historically been a route of economic advancement for disadvantaged groups. It has been argued, for example, that the economic success of earlier immigrant groups in the United States, such as the Chinese, Japanese, Jews, Italians, and Greeks, is in part due to their ownership of small businesses (See Loewen 1971, Light 1972, Baron 
et al. 1975, and Bonacich and Modell 1980). In addition, many states and the federal government are currently promoting self-employment as a way for families to leave the welfare and unemployment insurance rolls. ${ }^{1}$ The lack of business success among blacks also contributes to racial tensions in urban areas throughout the United States. The recent racial conflicts between Koreans and African-Americans in many large cities are in large part due to the presence of successful Korean-owned businesses in black communities (Yoon 1997 and Min 1996). It has also been argued that political influence comes with success in small business (Brown, Hamilton, and Medoff 1990).

Another reason for concern about the lack of business success among AfricanAmericans is that they have made little progress in rates of business ownership even in light of the substantial gains in education, earnings, and civil rights that they have made during the twentieth century. The 3 to 1 ratio of white to black self-employment rates noted above has remained roughly constant over the past 90 years (Fairlie and Meyer 2000). The question of why there was no convergence in racial self-employment rates over the twentieth century is an important one. Early researchers emphasized the role that past inexperience in business played in creating low rates of business ownership among blacks. In particular, Du Bois (1899), and later Myrdal (1944), Cayton and Drake (1946) and Frazier (1957) identify the lack of black traditions in business enterprise as a major cause of low levels of black business ownership at the time of their analyses.

The lack of black traditions in business argument relies on a strong intergenerational link in business ownership. Theoretically, we might expect the link to be strong due to the transmission of general business or managerial experience in family-

\footnotetext{
${ }^{1}$ See Guy, Doolittle, and Fink (1991) and Raheim (1997) for the AFDC program, and U.S. Department of Labor (1992) and Benus et al. (1995) for the UI program.
} 
owned businesses ("general business human capital"), the acquisition of industry- or firm-specific business experience in family-owned businesses ("specific business human capital"), the inheritance of family businesses, and the correlation among family members in preferences for entrepreneurial activities. ${ }^{2}$ Past empirical research supports this conjecture. The probability of self-employment is substantially higher among the children of the self-employed (see Lentz and Laband 1990, Fairlie 1999, Dunn and HoltzEakin 2000, and Hout and Rosen 2000). There is also evidence suggesting that current racial patterns of self-employment are in part determined by racial patterns of selfemployment in the previous generation (Fairlie 1999 and Hout and Rosen 2000).

Although these findings indicate that the intergenerational transmission of business ownership is important in creating racial disparities in rates of business ownership, little is known about whether it also contributes to racial disparities in business outcomes conditioning on ownership. Can these patterns explain why blackowned businesses have worse outcomes than white-owned firms? In particular, do black business owners have limited opportunities for the acquisition of general and specific business human capital from working in family-owned businesses and the receipt of business inheritances, in addition to less education and access to financial capital. And, can these disparities explain why black-owned businesses lag substantially behind whiteowned businesses in sales, profits, employment size and survival probabilities?

Previous studies have not examined these issues in detail primarily because only a few nationally representative datasets contain a large enough sample of black firms and

\footnotetext{
${ }^{2}$ Dunn and Holtz-Eakin (2000) consider an additional explanation. Successful business owners may be more likely to transfer financial wealth to their children potentially making it easier for them to become self-employed. Their empirical results, however, suggest that it plays only a modest role.
} 
information on parental and family self-employment, and to our knowledge, only one nationally representative dataset contains information on business inheritances and previous work experience in businesses owned by family members. ${ }^{3}$ The Characteristics of Business Owners (CBO) contains detailed information on the characteristics of both the business and the owner, but has been used by only a handful of researchers. The lack of use appears to be primarily due to difficulties in accessing and reporting results from these confidential, restricted-access data. All research using the $\mathrm{CBO}$ must be conducted in a Census Research Data Center or at the Center for Economic Studies (CES) after approval by the CES and IRS, and all output must pass strict disclosure regulations.

In this paper, we use data from the $\mathrm{CBO}$ to explore the role that intergenerational links in self-employment play in contributing to racial differences in small business outcomes, such as closures, profits, employment size, and sales. We build on previous findings using the $\mathrm{CBO}$ indicating that previous work experience in a family member's business and previous work experience in a business providing similar goods and services have large positive effects on small business outcomes, whereas having a self-employed family member and business inheritances play only a minor role (Fairlie and Robb 2003). A careful examination of how these measures of family business background differ by race may uncover some answers. The inability of blacks to acquire general and specific business human capital through exposure to businesses owned by family members may contribute to their limited success in business ownership.

\footnotetext{
${ }^{3}$ The CBO also contains information on prior work experience in a managerial capacity and prior work experience in a business whose goods/services were similar to those provided by the
} 


\section{Data}

The 1992 Characteristics of Business Owners (CBO) survey was conducted by the U.S. Bureau of the Census to provide economic, demographic and sociological data on business owners and their business activities (see U.S. Department of Commerce 1997, Bates 1990a, Headd 1999, and Robb 2000 for more details on the CBO). There were oversamples of black-, Hispanic-, other minority-, and female-owned businesses. The survey was sent to more than 75,000 firms and 115,000 owners who filed an IRS form 1040 Schedule C (individual proprietorship or self-employed person), 1065 (partnership), or $1120 \mathrm{~S}$ (subchapter S corporation). ${ }^{4}$ Only firms with $\$ 500$ or more in sales were included. The businesses included in the CBO represent nearly 90 percent of all businesses in the United States (Department of Commerce, 1996b). Response rates for the firm and owners surveys were approximately 60 percent. All estimates reported below use sample weights that adjust for survey non-response (Headd, 1999).

The $\mathrm{CBO}$ is unique in that it contains detailed information on both the characteristics of business owners and the characteristics of their businesses. For example, owner characteristics include education, detailed work experience, hours worked in the business and how the business was acquired, and business characteristics include profits, sales, employment and industry. Additional advantages of the CBO over other nationally representative datasets for this analysis are the availability of measures of business ownership among family members and the large oversample of black-owned businesses. In particular, the CBO contains information on business inheritances,

owner's business.

${ }^{4}$ Larger $\mathrm{C}$ corporations were not included because of the difficulty in asking owner questions for many investors. C corporations as a tax filing status, however, are becoming less popular relative to $\mathrm{S}$ corporations due to changes in tax laws (Headd 1999). 
business ownership among family members, and prior work experience in a family member's business. The main disadvantage is that the $\mathrm{CBO}$ does not contain information on a comparison group of wage/salary workers. Therefore, we cannot explore the causes of racial differences in the rates of business ownership. We can, however, examine the determinants of racial patterns in several business outcomes, such as closure rates, sales, profits, and employment size.

The sample used below includes firms that meet a minimum weeks and hours restriction. Specifically, at least one owner must report working for the business at least 12 weeks in 1992 and at least 10 hours per week. ${ }^{5}$ The weeks and hours restrictions are imposed to rule out very small-scale business activities such as casual or side-businesses owned by wage/salary workers. In multi-owner firms, which represent 20.6 percent of the sample, we identify one person as the primary owner of the business. The primary owner is identified as the owner working the most annual hours in 1992 (weeks*hours). In the case of ties, we identify the primary owner as the person who founded the business. Finally, all remaining ties are resolved by assigning a random owner. The primary business owner is used to identify all owner characteristics of the firm, such as marital status, education, prior work experience, and family business background. The race and sex of the firm, however, are identified by majority ownership, which is the method used by SMOBE/SWOBE (U.S. Bureau of the Census, 1996, Robb 2000). ${ }^{6}$

\footnotetext{
${ }^{5}$ This restriction excludes 22.1 percent of firms in the original sample.

${ }^{6}$ The race of the primary owner is not available in the $\mathrm{CBO}$, and the sex of the owner had many
} 


\section{Racial Differences in Small Business Outcomes}

Black-owned firms have worse outcomes than white-owned firms. Table 1

reports estimates of closure rates between 1992 and 1996, and 1992 profits, employment size, and sales from the CBO. The magnitude of these differences in business outcomes is striking. For example, only 13.9 percent of black-owned firms have annual profits of $\$ 10,000$ or more, compared to 30.4 percent of white-owned firms. In fact, the entire distribution of business net profits before taxes for black-owned firms is to the left of the distribution for white-owned firms (with the exception of the largest loss categories). ${ }^{7}$ Surprisingly, nearly 40 percent of all black-owned firms have negative profits. Blackowned firms also have lower survival rates than white-owned firms. The average probability of business closure between 1992 and 1996 is 26.9 percent for black-owned firms compared to 22.6 percent for white-owned firms. ${ }^{8}$

Black-owned firms are substantially smaller on average than are white-owned firms. Mean sales or total receipts among black-owned firms were \$59,415 in 1992. Average sales among white-owned firms were nearly 4 times larger. The difference is not simply due to a few very large white firms influencing the mean. Median sales for black firms were one half that of white firms, and the percent of black firms with sales of $\$ 100,000$ or more was less than half the percent of white firms. Black-owned firms also hire fewer employees than white-owned firms. On average, they hire only 0.63

missing values.

${ }^{7}$ The CBO only includes a categorical measure for profits.

${ }^{8}$ Although sample weights are used that correct for non-response, there is some concern that closure rates are underestimated for the period from 1992 to 1996. Many businesses closed or moved over this period and did not respond to the survey which was sent out at the end of the period. Indeed, Robb (2000) showed, through matching administrative records, that nonrespondents had a much higher rate of closure than respondents. Racial differences in closure rates, however, were similar across the respondents and nonrespondents. 
employees, whereas white-owned firms hire 1.80 employees. Interestingly, only 11.3 percent of black-owned firms hire any employees. In comparison, 21.4 percent of whiteowned firms hire at least 1 employee.

Estimates from other data sources paint a similarly bleak picture for the state of black business. Closure rates are high among black-owned firms (Bates 1997, Robb 2000, Boden and Headd 2002, and Robb 2002). Data from the Survey of Small Business Finances show that black owned businesses had lower sales, employment, and profits, as well has higher bankruptcies and credit risk ratings (Bitler, Robb, and Wolken, 2001). Using data from the Panel Study of Income Dynamics, Fairlie (1999) finds that the annual exit rate from self-employment for black men is twice the rate for white men.

\section{Racial Differences in Family Business Background}

An extensive literature addresses the "breakdown" of the African-American family (Wilson 1987, Tucker and Mitchell-Kernan 1995, Wilson 2002). Blacks are 40.1 percent less likely to be married than are whites, and black women are 78.8 percent more likely to have an out-of-wedlock birth than are white women (U.S. Bureau of the Census 2001 and National Center for Health Statistics 2002). The result is that 53.3 percent of black children live with only one of their parents compared to 21.5 percent of white children (U.S. Bureau of the Census 2001). In addition, previous research indicates that the probability of self-employment is substantially higher among the children of the selfemployed than among the children of the non-self-employed (see Lentz and Laband 1990, Fairlie 1999, Dunn and Holtz-Eakin 2000, and Hout and Rosen 2000). These

studies generally find that an individual who had a self-employed parent is roughly two to 
three times as likely to be self-employed as someone who did not have a self-employed parent. The high incidence of growing up in a single-parent family and the strong intergenerational link in self-employment may limit business ownership opportunities for blacks.

Concerns about the negative consequences of weak family ties on business opportunities among blacks are not new. In fact, four decades ago Nathan Glazer and Daniel Patrick Moynihan made the argument that the black family "was not strong enough to create those extended clans that elsewhere were most helpful for businessmen and professionals (Glazer and Moynihan 1970, p.33)." More recently, Hout and Rosen (2000) note a "triple disadvantage" faced by black men in terms of business ownership. They are less likely than white men to have self-employed fathers, to become selfemployed if their fathers were not self-employed, and to follow their father in selfemployment. Furthermore, Fairlie (1999) provides evidence from the PSID that current racial patterns of self-employment are in part determined by racial patterns of selfemployment in the previous generation.

We know less, however, about whether blacks and whites differ in work experience in family businesses and their likelihood of receiving business inheritances, and whether these patterns contribute to why black firms are less successful than white firms. Estimates from the $\mathrm{CBO}$ indicate that black and white primary business owners have different family business backgrounds. Table 2 reports the percentage of owners that had a family member who was a business owner and the percentage of owners that worked for that family member. ${ }^{9}$ More than half of all white business owners had a self-

\footnotetext{
${ }^{9}$ The questions ask (1) "Prior to beginning/acquiring this business, had any of your close relatives ever owned a business OR been self-employed? (Close relatives refer to spouses,
} 
employed family member owner prior to starting their business. In contrast, approximately one-third of black business owners had a self-employed family member.

Although family members may include spouses and siblings in addition to parents, these findings are consistent with Hout and Rosen's (2000) finding of a lower probability of self-employment among the children of self-employed parents (the "intergenerational pick up rate with respect to self-employment") for blacks than for whites. $^{10}$ To see this, we express the joint probability of having a self-employed parent $\left(\mathrm{S}_{\mathrm{t}-1}=1\right)$ and child $\left(\mathrm{S}_{\mathrm{t}}\right)$ as:

$$
\mathrm{P}\left(\mathrm{S}_{\mathrm{t}}=1, \mathrm{~S}_{\mathrm{t}-1}=1\right)=\mathrm{P}\left(\mathrm{S}_{\mathrm{t}}=1 \mid \mathrm{S}_{\mathrm{t}-1}=1\right) \mathrm{P}\left(\mathrm{S}_{\mathrm{t}-1}=1\right)=\mathrm{P}\left(\mathrm{S}_{\mathrm{t}-1}=1 \mid \mathrm{S}_{\mathrm{t}}=1\right) \mathrm{P}\left(\mathrm{S}_{\mathrm{t}}=1\right)
$$

Assuming a steady state equilibrium, $\mathrm{S}_{\mathrm{t}}=\mathrm{S}_{\mathrm{t}-1}$ and one-to-one matching of parents to children, the intergenerational pick up rate equals the probability of a business owner having a self-employed parent. We find a black/total ratio of .632 for the probability of having a self-employed family member, which is in the range of Hout and Rosen's (2000) estimates.

Family businesses may provide important opportunities for acquiring general and specific business human capital (Lentz and Leband 1990, Fairlie and Robb 2003). Estimates from the $\mathrm{CBO}$ indicate that conditional on having a self-employed family

parents/guardians, brothers, sisters, or immediate family)", and (2) "If "Yes," did you work for any of these relatives?" (U.S. Department of Commerce 1997, p. C-4).

${ }^{10}$ The percent of owners that had a self-employed family member prior to business startup certainly overstates the percent of owners that had a self-employed parent, but the discrepancy may not be that large. The strong positive influence of parental self-employment is common to brothers suggesting that a propensity for business ownership runs in families (Dunn and HoltzEakin 2000), and the question on the CBO asks whether the owner had a self-employed family member prior to starting his/her business limiting the likelihood that older siblings are referring to younger self-employed siblings. Furthermore, estimates from the 2002 Current Population Survey indicate that the average probability of having a self-employed spouse among all selfemployed business owners is only 24 percent. We suspect that a large percentage of affirmative responses to the $\mathrm{CBO}$ question on whether the owner had a self-employed family member prior to starting his/her business refer to the owner's parents. 
member, black business owners were also less likely to have worked for that person than were white business owners. Only 37.4 percent of black business owners who had a selfemployed family member worked for that person's business, whereas 43.9 percent of white business owners who had a self-employed family member worked for that person's business. ${ }^{11}$ Finally, black business owners overall were much less likely than white business owners to work for a family member's business. The unconditional rate of working for family member's business was 12.6 percent for blacks and 23.3 percent for whites.

Black business owners were slightly less likely to inherit their businesses than were white owners (Table 2). Only 1.4 percent of black owners inherited their firms compared to 1.7 percent of white owners. These rates of inheritance are very low and suggest that racial differences in inheritances cannot explain much of the gaps in small business outcomes.

Overall, the estimates reported in Table 2 indicate that black business owners have a relatively disadvantaged family business background compared to white business owners. The lack of family business experience may contribute substantially to the relative lack of success of black-owned businesses because of limited opportunities to receive the informal learning or apprenticeship type training that occurs in working in a family business. Family businesses provide an opportunity for family members to acquire general business human capital and in many cases also provide the opportunity for acquiring specific business human capital. The impact of racial differences in these opportunities on racial differences in small business outcomes, however, is an open

\footnotetext{
${ }^{11}$ These patterns may in part be due to lower employment levels among black-owned firms.
} 
question. To answer this question we next investigate the determinants of small business outcomes.

\section{The Determinants of Small Business Outcomes}

To better understand why racial differences in business outcomes exist, we first model the determinants of small business outcomes. Logit and linear regression models are estimated for the probability of a business closure from 1992-1996, the probability that the firm has profits of at least $\$ 10,000$ per year, the probability of having employees, and log sales. ${ }^{12}$ Table 3 reports estimates. We include the race, sex, region and urbanicity of the firm, and the education level, marital status and previous work experience of the owner as controls. We also include the family business background variables listed in Table 2 and two related business experience variables.

After controlling for numerous owner and business characteristics, black-owned businesses continue to lag behind white-owned businesses. In all specifications except the closure probability equation, the coefficient estimate on the black-owned business dummy variable is large, positive and statistically significant. In the closure probability equation, the coefficient estimate is positive, but statistically insignificant. Evidently, our regressors cannot explain all of the differences between blacks and whites in small business outcomes (we discuss these issues further in the next section).

\footnotetext{
${ }^{12}$ Although the profit measure is categorical, we do not estimate an ordered model because of the difficulty in interpreting the decomposition results that follow. The regression and decomposition results using a cutoff of $\$ 25,000$ are similar to those reported below. The other possible cutoff of $\$ 100,000$ yielded too few observations in which the dependent variable equals one. We also use a logit model for the employment probability because most of the variation in employment among small businesses is between 0 and 1 employee. Roughly 80 percent of firms have no employees and only a small percent have more than 5 employees.
} 
Similar to previous studies, we find that small business outcomes are positively associated with the education level of the business owner. ${ }^{13}$ For example, businesses with college-educated owners have a 0.055 lower probability of closure, a 0.113 higher probability of having large profits, a 0.060 higher probability of having employees, and have approximately 25 percent higher sales on average than businesses with owners who did not graduate from high school. ${ }^{14}$ Female-owned businesses are less successful and are smaller on average than are male-owned businesses. Firms located in urban areas are more likely to close and are less likely to have employees, but are more likely to have large profits and have higher sales than firms located in non-urban areas.

Having a family business background is important for small business outcomes. ${ }^{15}$ The main effect, however, appears to be through the informal learning or apprenticeship type training that occurs in working in a family business and not from simply having a self-employed family member. The coefficient estimates on the dummy variable indicating whether the owner had a family member who owned a business are small and statistically insignificant in all of the specifications except for the closure probability equation. In contrast, working at this family member's business has a large positive and statistically significant effect in all specifications. The probability of a business closure is 0.042 lower, the probability of large profits is 0.032 higher, the probability of employment is 0.055 higher, and sales are roughly 40 percent higher if the business owner had worked for one of his/her self-employed family members prior to starting the

\footnotetext{
${ }^{13}$ For example, using the $1982 \mathrm{CBO}$, Bates (1990b) finds that small business failures generally decrease with the education level of the owner.

${ }^{14}$ The implied effects on the probability of closure, profits, and employment are approximated by multiplying the coefficient estimate from the logit model by $\bar{p}(1-\bar{p})$, where $\bar{p}$ is the mean of the dependent variable.

${ }^{15}$ See Fairlie and Robb (2003) for a more detailed discussion of the effects of family business
} 
business. ${ }^{16}$ The effects on the closure, profit and employment probabilities represent 15.3 to 26.6 percent of the sample mean for the dependent variables.

Perhaps not surprisingly, inherited businesses are more successful and larger than non-inherited businesses. The coefficients are large, positive (negative in the closure equation) and statistically significant in all specifications. Inheritances may represent a form of transferring successful businesses across generations, but their overall importance in determining small business outcomes is slight at best. Although the coefficient estimates are large in the small business outcome equations, the relative absence of inherited businesses (only 1.6 percent of all small businesses) suggests that they play only a minor role in establishing an intergenerational link in self-employment. ${ }^{17}$

The strong effect of previous work experience in a family member's business on small business outcomes suggests that family businesses provide an important opportunity for family members to acquire human capital related to operating a business. The general lack of significance of having a self-employed family member may indicate that correlations across family members in entrepreneurial preferences are less important in creating an intergenerational link in business ownership.

The $\mathrm{CBO}$ also provides detailed information on other forms of acquiring general and specific business human capital. Available questions include information on prior work experience in a managerial capacity and prior work experience in a business whose goods and services were similar to those provided by the owner's business. These

background variables on small business outcomes.

${ }^{16}$ These estimates are not overly sensitive to the exclusion of firms started before 1980. In addition, estimates from the log sales specification are not sensitive to the exclusion of firms with extremely large annual sales.

${ }^{17}$ As expected, the removal of business inheritances from the specifications does not affect the coefficients on other variables. 
variables may have an important effect on small business outcomes. There may also exist important racial differences in the extent to which these methods of acquiring general and specific business human capital are used, thus leading in turn to racial differences in business outcomes.

The effects on small business outcomes of working for a self-employed family member are generally stronger than the effects of previous work experience in a managerial capacity. Management experience has a similar size effect in the profit and employer probability equations, but has a much smaller effect on log sales and a positive and statistically significant effect on business closures. Management experience prior to starting or acquiring a business generally improves business outcomes, but has a less consistent effect than experience working for a close relative.

The $\mathrm{CBO}$ also provides information on whether the owner worked in a business whose goods and services were similar to those provided by his/her business. This more general case of acquiring specific business human capital appears to be very important. In fact, the coefficient estimates on a dummy variable for whether the owner had work experience in a similar business are comparable in size to the coefficient estimates on prior work experience in a family member's business in the closure probability and log sales equations. The coefficient estimate is smaller in the employer probability equation, but larger in the profits equation. In all specifications, the coefficient estimates are large and statistically significant.

The inclusion of prior managerial experience and similar business experience suggests that the large, positive coefficient estimates on working for a self-employed family member are not simply capturing the effects of management experience or specific 
business human capital on small business outcomes. Instead, prior work experience in a family member's business has an independent effect on small business outcomes, which may in part be due to the acquisition of less specific, general business human capital. In contrast, the independent effects of having a family member who owns a business on small business outcomes are not large. Finally, inherited businesses may be more successful on average than non-inherited businesses, but their limited representation among the population of small businesses suggests that they are only a minor determinant of small business outcomes.

\section{MISSING DATA}

A concern with the estimates reported in Table 3 is the amount of missing data for some of the independent variables in the CBO. Approximately 10 percent of the observations for each of the specifications reported in Table 3 are excluded because of missing values for one or more of the independent variables. Although these levels of missing data are not extremely high, we examine the sensitivity of our results to two alternative methods of correcting for missing data. First, we estimate regressions in which dummy variables are included for missing values of specific independent variables. ${ }^{18}$ For example, if the education level of the business owner is missing then the four education level dummy variables would be equal to zero and a special missing education dummy variable would be equal to one. Thus, the missing observation for owner's education would not contribute to the coefficient estimates on the main education level dummies, but would contribute to coefficient estimates on other variables. This

\footnotetext{
${ }^{18}$ Race, gender, region, and urbanicty are from administrative record data and have no missing values.
} 
technique is becoming increasingly common in the literature because it is easy to implement and allows for an increase in the efficiency of some coefficient estimates. Although not reported, we find estimates that are similar to the ones reported in Table 2 for all four specifications.

We also address the missing data problem by using multiple imputation (see Rubin 1987, Schafer and Olsen 1998, and Schafer 1999 for more details). ${ }^{19}$ The multiple imputation technique essentially replaces each missing value in the data with a set of plausible values resulting in separate datasets that include the true values for nonmissing observations and the imputed variables for missing observations. The imputations are made by examining correlations between all available independent variables and placing restrictions on minimum and maximum values and rounding. ${ }^{20}$ The variables are assumed to have a multivariate normal distribution. Logit or linear regressions are then run on five separately imputed datasets. ${ }^{21}$ The results from the five runs are combined for inference and adjustments are made for sampling variance. The resulting coefficient estimates summarize this information and their standard errors capture the variability of estimates across the five runs, which differs from the typical overstatement of the statistical precision of estimates from single imputation methods. We report the multiple imputation coefficient estimates and their standard errors in Appendix 1. Despite the large increase in sample size, the estimates are similar to those reported in Table 3. Thus,

\footnotetext{
${ }^{19}$ The technique has been discussed recently in the Economics literature (Brownstone and Valetta 2001) and has been used to impute income and wealth variables in the Survey of Consumer Finances (Kennickell 1998).

${ }^{20}$ Information from all of the independent variables in the main specification, in addition to information on financial capital, industry, and start year, was used in the correlations.

${ }^{21}$ The gains in efficiency are small after increasing the number of imputations above five (Schafer and Olsen 1998).
} 
the removal of observations with missing data does not appear to overly affect our results.

\section{FINANCIAL STARTUP CAPITAL AND INDUSTRY}

Several previous studies find that asset levels play an important role in determining who enters into or exits from self-employment. ${ }^{22}$ Furthermore, recent studies show that blacks have substantially lower levels of assets than whites and that these differences contribute to racial differences in business ownership levels. ${ }^{23}$ There is also evidence suggesting that black-owned businesses experience higher loan denial probabilities and pay higher interest rates than white-owned businesses even after controlling for differences in credit-worthiness and other factors (Blanchflower, Levine and Zimmerman 2001 and Cavalluzzo, Cavalluzzo, and Wolken 2002). These findings suggest that racial differences in access to and levels of startup capital may contribute to black/white disparities in small business outcomes.

Black- and white-owned firms are found in different industries (see Robb 2000 and U.S. Bureau of the Census 1997 for evidence). Racial differences in industry distributions may contribute to black/white differences in small business outcomes. Certain industries have higher business turnover rates than others, most notably retail and services (Robb 2000, Reynolds and White 1997, and Humphreys and McClung 1981). Those with higher capital requirements for entry, such as manufacturing and wholesale,

\footnotetext{
${ }^{22}$ See Evans and Jovanovic (1989), Evans and Leighton (1989), Bates (1990b), Holtz-Eakin, Joulfaian, and Rosen (1994a,1994b), Blanchflower and Oswald (1998), and Dunn and HoltzEakin (2000).

${ }^{23}$ See Blau and Graham (1992), Oliver and Shapiro (1995) and Menchik and Jianakoplos (1997) for racial differences in asset levels, and Bates (1989), Meyer (1990) and Fairlie (1999) for evidence on their contributions to racial differences in self-employment.
} 
typically have lower turnover rates. Barriers of entry into specific industries can result for many reasons. First, capital constraints can limit which industries an individual can enter due to higher capital requirements of certain industries (Bates, 1997). In addition, industry choice may be constrained due to a lack of relevant skills, discrimination, or differences in preferences (Boden, 1996, Boden and Nucci 2000, and Robb, 2000).

To further explore these issues, we estimate a second set of small business outcome regressions that include dummy variables for different levels of startup capital and major industry categories. The CBO contains categorical information on "the total amount of capital required to start/acquire the business" (U.S. Department of Commerce 1997. p. C-15). Estimates are reported in Table 4. Some caution is required in interpreting the results, however, as the amount of required startup capital is potentially endogenous to business success (Bates 1990b). ${ }^{24}$ Furthermore, the choice of industry may not be entirely exogenous as it is related to the business decision.

As expected, small business outcomes are positively associated with the amount of required startup capital. The coefficients on the startup capital dummies are large, positive (negative for the closure probability), and statistically significant in all specifications. Industry is also linked to business success and size although the coefficients vary across specifications. The addition of startup capital and industry does not overly influence the estimated effects of the family business background and similar

\footnotetext{
${ }^{24}$ A similar problem occurs in examining whether asset levels affect the probability of selfemployment using cross-sectional data. A correlation between assts and self-employment may simply represent the ability of the self-employed to accumulate more assets than wage/salary workers through operating and owning their own businesses. The approach taken in several recent studies is to examine transitions into self-employment measuring an individual's net worth prior to starting a business (see Evans and Jovanovic 1989, Evans and Leighton 1989, Meyer 1990, Holtz-Eakin, Joulfaian, and Rosen 1994a, Fairlie 1999, and Dunn and Holtz-Eakin 2000). Unfortunately, the CBO does not contain a measure of the owner's net worth prior to starting the
} 
business experience variables. The coefficient estimates on previous work experience in a family member's business are generally smaller in absolute value (although statistically significant) in the new specifications. The coefficients on prior work experience in a similar business are very similar. The black coefficients, however, decline precipitously in absolute value in all, but one of the specifications. We discuss this issue further in the next section.

\section{Identifying the Causes of Racial Differences in Small Business Outcomes}

Estimates from the $\mathrm{CBO}$ indicate that black business owners have less family business experience than white business owners (Table 2). They also have lower levels of education and startup capital, and differ from white business owners along other lines (Appendix 2). Furthermore, the estimates reported in Tables 3 and 4 indicate that many of these variables are important determinants of small business outcomes. Taken together these results suggest that racial differences in family business background, education, and startup capital contribute to why black-owned businesses have worse outcomes on average than white-owned businesses. The impact of each factor, however, is difficult to summarize. In particular, we wish to identify the separate contributions from racial differences in the distributions of all of the variables or subsets of variables included in the regressions.

To explore these issues further, we employ a variant of the familiar technique of decomposing inter-group differences in a dependent variable into those due to different observable characteristics across groups and those due to different "prices" of characteristics of groups (see Blinder 1973 and Oaxaca 1973). The technique that we

business. 
describe here takes into account the nonlinearity of the logit regressions used to estimate the closure, profit, and employment probability equations discussed above. ${ }^{25}$ We use the standard Blinder-Oaxaca decomposition for the log sales specification.

For a linear regression, the standard Blinder-Oaxaca decomposition of the white/minority gap in the average value of the dependent variable, Y, can be expressed as: (5.1) $\bar{Y}^{W}-\bar{Y}^{M}=\left\lfloor\left(\bar{X}^{W}-\bar{X}^{M}\right) \hat{\beta}^{W}\right\rfloor+\left[\bar{X}^{M}\left(\hat{\beta}^{W}-\hat{\beta}^{M}\right)\right\rfloor$ where $\bar{X}^{j}$ is a row vector of average values of the independent variables and $\hat{\beta}^{j}$ is a vector of coefficient estimates for race $j$. For a nonlinear equation, such as $Y=F(X \hat{\beta})$, the decomposition can be written as:

$$
\bar{Y}^{W}-\bar{Y}^{M}=\left[\sum_{i=1}^{N^{W}} \frac{F\left(X_{i}^{W} \hat{\beta}^{W}\right)}{N^{W}}-\sum_{i=1}^{N^{M}} \frac{F\left(X_{i}^{M} \hat{\beta}^{W}\right)}{N^{M}}\right]+\left[\sum_{i=1}^{N^{M}} \frac{F\left(X_{i}^{M} \hat{\beta}^{W}\right)}{N^{M}}-\sum_{i=1}^{N^{M}} \frac{F\left(X_{i}^{M} \hat{\beta}^{M}\right)}{N^{M}}\right]
$$

where $N^{j}$ is the sample size for race $j$. This alternative expression for the decomposition is used because $\bar{Y}$ does not necessarily equal $F(\bar{X} \hat{\beta})$. In both (5.1) and (5.2), the first term in brackets represents the part of the racial gap that is due to group differences in distributions of $X$, and the second term represents the part due to differences in the group processes determining levels of $Y$. To calculate the decomposition, define $\bar{Y}$ as the mean business outcome and $F$ as the logistic cumulative distribution function. ${ }^{26}$

\footnotetext{
${ }^{25}$ See Fairlie (1999) for more details.

${ }^{26}$ A useful property of the logit regression that includes a constant term, is that the average of the predicted probabilities must equal the proportion of ones in the sample. In contrast, the predicted probability evaluated at the means of the independent variables is not necessarily equal to the proportion of ones, and in the sample used here it is likely to be smaller because the logit function is convex for values less than 0.5 .
} 
An equally valid method of calculating the decomposition is to use the minority coefficient estimates, $\hat{\beta}^{M}$, as weights for the first term and the white distributions of the independent variables, $\bar{X}^{W}$, as weights for the second term. This alternative method of calculating the decomposition often provides different estimates, which is the familiar index problem with the Blinder-Oaxaca decomposition technique. A third alternative is to weight the first term of the decomposition expression using coefficient estimates from a pooled sample of the two groups (see Oaxaca and Ransom 1994 for example). We follow this approach to calculate the decompositions. In particular, we use coefficient estimates from a logit regression that includes a sample of all racial groups.

The first term in (5.2) provides an estimate of the contribution of racial differences in the entire set of independent variables to the racial gap. An additional calculation, however, is needed to identify the contribution of racial differences in specific variables to the gap. For example, assume that $X$ includes two variables, $X_{l}$ and $X_{2}$. The independent contribution of $X_{1}$ to the racial gap can then be expressed as:

(5.3) $\frac{1}{N^{M}} \sum_{i=1}^{N^{M}} F\left(X_{1 i}^{W} \hat{\beta}_{I}^{*}+X_{2 i}^{W} \hat{\beta}_{2}^{*}\right)-F\left(X_{1 i}^{M} \hat{\beta}_{I}^{*}+X_{2 i}^{W} \hat{\beta}_{2}^{*}\right)$,

where $\hat{\beta}^{*}$ is the vector of pooled coefficients. Similarly, the contribution of $X_{2}$ can be expressed as:

(5.4) $\frac{1}{N^{M}} \sum_{i=1}^{N^{M}} F\left(X_{1 i}^{M} \beta_{1}^{*}+X_{2 i}^{W} \beta_{2}^{*}\right)-F\left(X_{1 i}^{M} \beta_{1}^{*}+X_{2 i}^{M} \beta_{2}^{*}\right)$.

The contribution of each variable to the gap is thus equal to the change in the average predicted probability from replacing the white distribution with the minority distribution 
of that variable while holding the distribution of the other variable constant. ${ }^{27}$ The calculation of (5.3) and (5.4), however, is not possible without first matching the white distribution of $\mathrm{X}_{1}$ and the minority distribution of $\mathrm{X}_{2}$. We draw a random subsample of whites with a sample size equal to $\mathrm{N}_{\mathrm{B}}$ and randomly match it to the minority sample.

The decomposition estimates obtained from this procedure depend on the randomly chosen subsample of whites. Therefore, to obtain estimates that use the entire white sample, we draw a large number of random white subsamples. We then calculate the mean value of estimates from all of these samples. In the decompositions reported below, we use 1000 random subsamples of whites to calculate these means.

Table 5 reports estimates from this procedure for decomposing the black/white gaps in small business outcomes. The separate contributions from racial differences in each set of independent variables are reported. As noted above, the black/white gaps in small business outcomes are large. Racial differences in the male/female ownership of the firm contribute significantly to the gaps in small business outcomes. The large contributions are the result of a higher percentage of black-owned firms also being female-owned than white-owned firms, and the less successful and smaller nature of female-owned businesses overall. Lower marriage rates among blacks also contribute to the black/white gaps in small business outcomes.

Although racial disparities in education are smaller for business owners than the general population, low levels of education among black business owners relative to white business owners appear to have a negative effect on business outcomes. Twentyseven percent of black business owners have a college education compared to 33.2

\footnotetext{
${ }^{27}$ Unlike in the linear case, the independent contributions of $X_{1}$ and $X_{2}$ depend on the value of the other variable. This implies that the choice of a variable as $X_{1}$ or $X_{2}$ (or the order of switching the
} 
percent of white business owners (see Appendix 2). ${ }^{28}$ These educational differences, however, do not translate into large effects as racial differences in the education level of the owner explain from 2.4 to 6.5 percent of the black/white gaps in small business outcomes. Black business owners are less educated on average than are white business owners, but this appears to be only a minor hindrance to starting and running successful businesses.

Although black-owned businesses have a different regional distribution and are more likely to be located in urban areas than are white-owned businesses, racial differences in geographical locations do not appear to contribute substantially to the gaps in small business outcomes. Racial differences in the amount of prior work experience and management experience either have small effects or have mixed effects across specifications.

As reported in Table 2, black business owners are much less likely to have a selfemployed family member than are white business owners. This difference, however, is unimportant in explaining racial disparities in profits, employment, and sales. The only exception is that racial differences in having a self-employed family member explain 8.9 percent of the black/white gap in closure rates. The contribution of group differences in parental self-employment to racial differences in small business outcomes appears to be smaller than the contribution to rates of self-employment and entry into self-employment. Estimates from the PSID indicate that differences in the probability of having a selfemployed father explain 8 to 14 percent of the black/white gap in the entry rate into selfemployment and 4 to 6 percent of the gap in the self-employment rate (Fairlie 1999).

distributions) is potentially important in calculating its contribution to the racial gap.

${ }^{28}$ For all adults ages 25 and over, 11.9 percent of blacks and 22.1 percent of whites completed 4 
The explanatory power of racial differences in prior work experience in a family member's business is stronger. With the exception of the profits specification, racial differences in this variable explain 5.6 to 11.6 percent of the black/white gaps in small business outcomes. Apparently, the lack of work experience in family businesses among future black business owners, perhaps by restricting their acquisition of general and specific business human capital, limits the successfulness of their businesses relative to whites.

Providing some additional evidence on this point, racial differences in prior work experience in a business providing similar goods and services consistently explain a small part of the gaps in outcomes. Although the coefficient estimates in the small business outcome regressions were generally similar in magnitude to coefficient estimates on the family business work experience variable, the contributions from racial differences are somewhat smaller. The racial disparity in the percent of owners that worked in a family member's business is larger than the disparity in the percent of owners that worked in a business with similar goods and services (Table 2).

Black-owned businesses are less likely to be inherited than white-owned businesses and inherited businesses are generally more successful than non-inherited businesses, but racial differences in business inheritances explain virtually none of the gaps in small business outcomes. The overall likelihood of business inheritances (1.6 percent) is just too small to play a major role in explaining racial differences in business outcomes.

The finding is interesting in light of the finding in the literature that blacks are less likely to receive inheritances and typically receive much smaller inheritances than 
whites. In fact, there is recent evidence suggesting that the lack of inheritances among blacks is one of the primary factors explaining why blacks have asset levels that are substantially lower than white levels (Menchik and Jianakoplos 1997, Gittleman and Wolff 2000, and Avery and Rendall 2002). Furthermore, the receipt of inheritances is a major determinant of starting businesses (Holtz-Eakin, Joulfaian, and Rosen 1994a and Blanchflower and Oswald 1998) suggesting that lower levels of inheritances among blacks contributes to lower rates of business ownership. Focusing on business inheritances and small business outcomes, however, apparently changes the conclusion on the importance of racial differences in inheritances.

Table 6 reports the results of decompositions that include contributions from racial differences in startup capital and industry. Again, there is some concern about the exogeneity of these two measures in determining small business outcomes, and thus the results should be interpreted with caution. Black-owned firms generally required less startup capital than white-owned firms. For example, 8.1 percent of black-owned businesses required at least $\$ 25,000$ in startup capital compared to 15.7 percent of whiteowned businesses. These racial differences in startup capital explain a substantial portion of the black/white gaps in small business outcomes. The contribution estimates range from 14.5 to 43.2 percent. ${ }^{29}$ Clearly, lower levels of startup capital among black-owned firms are associated with less successful businesses. These lower levels of startup capital may be related to the types or scale of businesses that they choose to start, or it could be related to difficulty in obtaining funding (see Cavalluzzo, Cavalluzzo, and Wolken 2002,

\footnotetext{
${ }^{29}$ Fairlie (1999) finds that racial differences in asset levels explain approximately 15 percent of the black/white gap in transition rates into self-employment and from 1.8 to 11.1 percent of the black/white gap in transition rates out of self-employment.
} 
Cavalluzzo and Wolken 2002, and Blanchflower, Levine and Zimmerman 2001 for evidence of lending discrimination against black-owned firms). ${ }^{30}$

Black-owned businesses appear to be overrepresented in less successful industries relative to white-owned businesses. Racial differences in industry composition explain from 7.0 to 20.5 percent of the black/white gaps in small business outcomes. In particular, black-owned firms are more likely to be located in personal services, which have worse outcomes on average than other industries. These findings are consistent with Robb (2000). The results are difficult to interpret, however, because of the joint decision between business ownership and industry.

Overall, racial differences in the explanatory variables explain a large percentage of the total black/white gaps in small business outcomes. They explain nearly 50 percent of the racial gap in profits or employment, and nearly 70 percent of the total gap in log sales. The entire black/white gap in business closure rates is explained by racial differences in the explanatory variables. The remaining or "unexplained" portion of the racial gaps in small business outcomes may be due to lending discrimination and consumer discrimination against black-owned firms, the omission of important unmeasurable factors such as risk aversion, or the inability to accurately measure racial differences in access to capital. ${ }^{31}$

\section{Conclusions}

\footnotetext{
${ }^{30}$ Interestingly, black-owned firms have lower levels of startup capital across all major industries (U.S. Department of Commerce 1997).

${ }^{31}$ See Cavalluzzo, Cavalluzzo, and Wolken, 2002, Blanchflower, Levine and Zimmerman 1998, Borjas and Bronars (1989), and Meyer (1990) for evidence on lending and consumer discrimination against blacks, and see Fairlie (2002) for evidence on risk aversion.
} 
An important finding in the rapidly growing literature on self-employment is that the probability of business ownership is substantially higher among the children of business owners than among the children of non-business owners (Lentz and Laband 1990, Fairlie 1999, Dunn and Holtz-Eakin 2000, and Hout and Rosen 2000). Recent evidence also suggests that current racial patterns of self-employment are in part determined by racial patterns of self-employment in the previous generation (Fairlie 1999 and Hout and Rosen 2000). Using data from the confidential and restricted access Characteristics of Business Owners Survey, we expand on these results by exploring whether the intergenerational transmission of business ownership is also important in creating racial disparities in business outcomes conditioning on ownership. In particular, we explore whether limited opportunities for the acquisition of general and specific business human capital from working in family-owned businesses and the receipt of business inheritances, in addition to education, financial capital and geographical location, can explain why black-owned businesses lag substantially behind white-owned businesses in sales, profits, employment size and survival probabilities?

Estimates from the $\mathrm{CBO}$ indicate that black-owned firms have lower profits and sales, hire fewer employees, and are more likely to close than white-owned businesses. We also find that black business owners have a relatively disadvantaged family business background compared to white business owners. Black business owners are much less likely than white business owners to have had a self-employed family member owner prior to starting their business and are less likely to have worked in that family member's business. Only 12.6 percent of black business owners had prior work experience in a family member's business compared to 23.3 percent of white business owners. Racial 
differences and overall rates of business inheritances were much smaller. The percent of business owners inheriting their firms was 1.4 percent for blacks and 1.7 percent for whites.

Using a nonlinear decomposition technique, we find that the lower probability of having a self-employed family member prior to business startup among blacks than among whites does not generally contribute to racial differences in small business outcomes. Instead, the lack of prior work experience in family businesses among future black business owners, perhaps by restricting their acquisition of general and specific business human capital, limits the successfulness of their businesses relative to whites. With the exception of the profits specification, racial differences in this variable explain 5.6 to 11.6 percent of the gaps in small business outcomes. Providing some additional evidence on the importance of limited opportunities for acquiring business human capital, racial differences in prior work experience in similar businesses also consistently explain part of the gaps in small business outcomes. Furthermore, the combination of these two factors suggests that racial differences in opportunities to acquire business human capital in general contribute substantially to black/white differences in small business outcomes.

Black-owned businesses are less likely to be inherited than white-owned businesses and inherited businesses are generally more successful than non-inherited businesses, but racial differences in business inheritances explain virtually none of the gaps in small business outcomes. The overall likelihood of business inheritances (1.6 percent) is just too small to play a major role in explaining racial differences in business outcomes. 
We also examine the contributions of other factors to racial differences in small business outcomes. Lower levels of education among black business owners relative to white business owners explain a modest portion (2.4 to 6.5 percent) of the black/white gaps in small business outcomes. Although black-owned businesses have a different regional distribution and are more likely to be located in urban areas than are whiteowned businesses, racial differences in geographical locations do not appear to contribute substantially to the gaps in small business outcomes. Racial differences in the amount of prior work experience and management experience either have small effects or have mixed effects across specifications. Lower levels of startup capital among black-owned firms, however, are associated with less successful businesses. Racial differences in startup capital explain from 14.5 to 43.2 percent of the gaps in small business outcomes. Although the contributions are large, the results should be interpreted with caution because of endogeneity issues.

Our estimates indicate that blacks are less likely than whites to have previous work experience in a family member's business and are less likely to have previous work experience in a similar business. The relative lack of opportunities for acquiring general and specific business human capital apparently has a negative effect on the outcomes of black-owned firms. This finding has important policy implications. Most minority business development policies currently in place, such as set-asides and loan assistance programs, are targeted towards alleviating financial constraints not towards providing opportunities for work experience in small businesses. To break the "vicious" cycle of low rates of business ownership and negative business outcomes being passed from one generation of blacks to the next, programs that directly address deficiencies in family 
business experience, possibly through an expansion of apprenticeship-type entrepreneurial training programs, may be needed. 


\section{References}

Avery, RB and M.S. Rendall. 2002. "Lifetime Inheritances of Three Generations of Whites and Blacks," American Journal of Sociology, 107 (5): 1300-1346.

Baron, Salo W., et al. 1985. Economic History of the Jews, New York: Schocken.

Bates, Timothy. 1989. "The Changing Nature of Minority Business: A Comparative Analysis of Asian, Nonminority, and Black-Owned Businesses." The Review of Black Political Economy, 18, Fall: 25-42.

Bates, Timothy. 1990. "The Characteristics of Business Owners Data Base," Journal of Human Resources 25(4): 752-56.

Bates, Timothy. 1990. "Entrepreneur Human Capital Inputs and Small Business Longevity," Review of Economics and Statistics 72 (4): 551-59.

Bates, Timothy. 1997. Race, Self-Employment \& Upward Mobility: An Illusive American Dream, Washington, D.C.: Woodrow Wilson Center Press and Baltimore: John Hopkins University Press.

Benus, J. M., Johnson, T. R, Wood, M., Grover, N., \& Shen, T. 1995. Self-employment programs: A new reemployment strategy: Final report on the UI Self-Employment Demonstration (Unemployment Insurance Occasional Paper 95-4). Washington, DC: U.S. Department of Labor, Employment and Training Administration, Unemployment Insurance Service.

Bitler, Marianne, Alicia Robb, and John Wolken, 2001. "Financial Services Used by Small Businesses: Evidence from the 1998 Survey of Small Business Finances" Federal Reserve Bulletin, Vol. 87, April 2001.

Blanchflower, David G., and Andrew J. Oswald. 1998. "What Makes an Entrepreneur?" Journal of Labor Economics, 16 (1), pp. 26-60.

Blanchflower, David G., Phillip B. Levine, and David J. Zimmerman (2001). "Discrimination in the Small Business Credit Market," Dartmouth College Working Paper.

Blau, Francine, and David Graham (1990): "Black-White Differences in Wealth and Asset Composition," Quarterly Journal of Economics, pp. 321-339.

Blinder, Alan S. 1973. "Wage Discrimination: Reduced Form and Structural Variables." Journal of Human Resources 8: 436-455.

Boden, R. (1996), "Gender and Self-Employment Selection: An Empirical Assessment," Journal of Socio-Economics, 25(6), pp. 671-682. 
Boden, Rick and Brian Headd. 2002. "Race and Gender Differences in Business Ownership and Business Turnover." Business Economics, October.

Boden R. and A. Nucci (2002), “On the Survival Prospects of Men's and Women's New Business Ventures," Journal of Business Venturing.

Bonacich, Edna and John Modell. 1980. The Economic Basis of Ethnic Solidarity in the Japanese American Community. Berkeley: University of California Press.

Borjas, George, and Stephen Bronars (1989): "Consumer Discrimination and SelfEmployment," Journal of Political Economy, 97, pp. 581-605.

Brown, Charles, James Hamilton, and James Medoff. 1990. Employers Large and Small, Cambridge: Harvard University Press.

Brownstone, David, and Robert Valletta. 2001. "The Bootstrap and Multiple Imputations: Harnessing Increased Computing Power for Improved Statistical Tests," Journal of Economic Perspectives, 15 (4): 129-141.

Cavalluzzo, Ken, Linda Cavalluzzo, and John Wolken. 2002. "Competition, Small Business Financing, and Discrimination: Evidence from a New Survey," Journal of Business, Vol. 25 no. 4.

Cavalluzzo, Ken and John Wolken. 2002. "Small Business Loan Turndowns, Personal Wealth and Discrimination." Finance and Economics Discussion Series 2002-35, Board of Governors of the Federal Reserve System, August 2002.

Cayton, Horace R. and St. Clair Drake. 1946. Black Metropolis. London: Jonathan Cape.

Du Bois, W.E.B. 1899. The Philadelphia Negro, Philadelphia: University of Pennsylvania.

Dunn, Thomas A. and Douglas J. Holtz-Eakin. 2000. "Financial Capital, Human Capital, and the Transition to Self-Employment: Evidence from Intergenerational Links," Journal of Labor Economics 18 (2): 282-305.

Evans, David and Boyan Jovanovic. 1989. "An Estimated Model of Entrepreneurial Choice Under Liquidity Constraints." Journal of Political Economy 97(4):808-27.

Evans, David, and Linda Leighton (1989): "Some Empirical Aspects of Entrepreneurship," American Economic Review, 79, pp. 519-535. 
Fairlie, Robert W. 1999. "The Absence of the African-American Owned Business: An Analysis of the Dynamics of Self-Employment." Journal of Labor Economics, 17(1): 80108.

Fairlie, Robert W. 2002. "Drug Dealing and Legitimate Self-Employment," Journal of Labor Economics 20 (3): 538-567.

Fairlie, Robert W., and Bruce D. Meyer. 2000. "Trends in Self-Employment among Black and White Men: 1910-1990." Journal of Human Resources, 35(4): 643-669.

Fairlie, Robert W., and Alicia Robb. 2003. "Families, Human Capital, and Small Businesses: Evidence from the Characteristics of Business Owners Survey," Economic Growth Center, Yale University, Center Discussion Paper No. 871.

Frazier, E. Franklin (1957): The Negro in the United States, 2nd Edition, New York: McMillan.

Gittleman, Maury, and Edward N. Wolff. 2000. "Racial Wealth Disparities: Is the Gap Closing?" Working Paper.

Glazer, Nathan and Daniel P. Moynihan. 1970. Beyond the Melting Pot: the Negroes, Puerto Ricans, Jews, Italians, and Irish of New York City, 2nd Edition. Cambridge: MIT Press.

Guy, Cynthia, Fred Doolittle, and Barbara Fink. 1991. Self-Employment for Welfare Recipients: Implementation of the SEID Program. New York: Manpower Demonstration Research Corporation.

Headd, Brian. 2002. "Redefining Business Success: Distinguishing Between Closure and Failure," Small Business Economics, forthcoming.

Headd, Brian. 1999. "The Characteristics of Business Owners Database, 1992." U.S. Census Bureau, Center for Economic Studies, Working Paper Series, CES-WP-99-8.

Holtz-Eakin, Douglas, Joulfaian, David, and Rosen, Harvey. 1994. "Entrepreneurial Decisions and Liquidity Constraints." Rand Journal of Economics 23: 334-347.

Holtz-Eakin, Douglas, David Joulfaian, and Harvey Rosen. 1994. "Sticking It Out: Entrepreneurial Survival and Liquidity Constraints," Journal of Political Economy, pp. 53-75.

Hout, Michael and Harvey S. Rosen. 2000. "Self-Employment, Family Background, and Race," Journal of Human Resources., 35 (4): 670-692.

Humphreys, M.A. and McClung J. (1981). "Women Entrepreneurs in Oklahoma," Review of Regional Economics and Business, 6 (2), 13-20. 
Kennickell, Arthur B. 1998. "Multiple Imputation in the Survey of Consumer Finances," Paper Prepared for the August 1998 Joint Statistical Meetings.

Lentz, Bernard, and David Laband. 1990. "Entrepreneurial Success and Occupational Inheritance among Proprietors," Canadian Journal of Economics, 23, No. 3, pp. 563-579.

Light, Ivan. 1972. Ethnic Enterprise in America. Berkeley: University of California Press.

Loewen, James W. 1971. The Mississippi Chinese: Between Black and White. Cambridge: Harvard University Press.

Meyer, Bruce. 1990. "Why Are There So Few Black Entrepreneurs?" National Bureau of Economic Research, Working Paper No. 3537.

Min, Pyong Gap. 1996. Caught in the Middle: Korean Merchants in America's Multiethnic Cities. Berkeley: University of California Press.

Menchik, Paul L. and Nancy A. Jianakoplos. 1997. "Black-White Wealth Inequality: Is Inheritance the Reason?," Economic Inquiry, 35(2), p. 428-442.

Myrdal, Gunnar. 1944. An American Dilemma, New York: Harper and Brothers.

National Center for Health Statistics. 2002. "Births: Final Data for 2001," National Vital Statistics Reports, Volume 51, Number 2. Washington, D.C.: Centers for Disease Control and Prevention.

Oaxaca, Ronald. 1973. "Male-Female Wage Differentials in Urban Labor Markets," International Economic Review, 14 (October), 693-709.

Oaxaca, Ronald, and Michael Ransom. 1994. "On Discrimination and the Decomposition of Wage Differentials," Journal of Econometrics, 61, 5-21.

Oliver, Melvin L. and Thomas M. Shapiro. 1995. Black Wealth/White Wealth: A New Perspective on Racial Inequality, New York: Routledge.

Raheim, Salome (1997): "Problems and prospects of self-employment as an economic independence option for welfare recipients," Social Work, 42, 1, pp. 44-53.

Reynolds, P. and S. White (1996), The Entrepreneurial Process: Economic Growth, Men, Women, and Minorities. Quorum Books, Westport.

Robb, Alicia. 2002. "Entrepreneurship: A Path for Economic Advancement for Women and Minorities?," Journal of Developmental Entrepreneurship, Volume 7, No. 4. 
Robb, Alicia. 2000. "The Role of Race, Gender, and Discrimination in Business Survival", Doctoral Dissertation, University of Michigan Press.

Rubin, Donald B. 1987. Multiple Imputation for Nonresponse in Surveys, New York: John Wiley.

Schafer, Joseph L. 1999. "Multiple Imputation: a Primer," Statistical Methods in Medical Research, 8: 3-15.

Schafer, Joseph L., and Maren K. Olsen. 1998. "Multiple Imputation for Multivariate Missing-Data Problems: A Data Analyst's Perspective," Multivariate Behavioral Research, 33 (4): 545-571.

Tucker, M. Belinda, and Claudia Mitchell-Kernan. 1995. The Decline in Marriage Among African-Americans: Causes, Consequences, and Policy Implications. New York: Russell Sage Foundation.

U.S. Bureau of the Census. 1993. 1990 Census of the Population, Social and Economic Characteristics, United States, Washington D.C.: Government Printing Office.

U.S. Bureau of the Census. 1994. "Educational Attainment in the United States: March 1993 and 1992," Current Population Reports, Population Characteristics, P20-476.

U.S. Bureau of the Census. 1996. 1992 Survey of Minority Owned Business Enterprises, Black. Washington, D.C.: Government Printing Office.

U.S. Bureau of the Census. 2001. "America's Families and Living Arrangements: March 2000," Current Population Reports, P20-537. U.S. Census Bureau: Washington, D.C.

U.S. Department of Commerce. 1997. 1992 Economic Census: Characteristics of Business Owners. Washington, D.C.: U.S. Government Printing Office.

U.S. Department of Labor. 1992. Self-Employment Programs for Unemployed Workers. Unemployment Insurance Occasional Paper 92-2. Washington: USGPO.

Wilson, William J. 1987. The Truly Disadvantaged: The Inner City, the Underclass, and Public Policy. Chicago: University of Chicago Press.

Wilson, James Q. 2002. The Marriage Problem: How Our Culture Has Weakened Families, New York: HarperCollins.

Yoon, In-Jin. 1997. On My Own: Korean Businesses and Race Relations in America, Chicago: University of Chicago Press. 
Table 1

Small Business Outcomes by Race

Characteristics of Business Owners, 1996

\begin{tabular}{lccc} 
& All Firms & $\begin{array}{c}\text { White-Owned } \\
\text { Firms }\end{array}$ & $\begin{array}{c}\text { Black-Owned } \\
\text { Firms }\end{array}$ \\
\hline $\begin{array}{l}\text { Percent of firms in 1992 no longer } \\
\text { operating in } 1996 \text { (Closure) }\end{array}$ & $22.5 \%$ & $22.6 \%$ & $26.9 \%$ \\
$\begin{array}{l}\text { Percent of firms with a net profit of at } \\
\text { least } \$ 10,000\end{array}$ & $30.1 \%$ & $30.4 \%$ & $13.9 \%$ \\
$\begin{array}{l}\text { Percent of firms with a positive net } \\
\text { profit }\end{array}$ & $74.5 \%$ & $75.1 \%$ & $60.7 \%$ \\
$\begin{array}{l}\text { Percent of firms with 1 or more paid } \\
\text { employees }\end{array}$ & $21.3 \%$ & $21.4 \%$ & $11.3 \%$ \\
Mean number of employees & 1.77 & 1.80 & 0.63 \\
Mean sales & $\$ 212,791$ & $\$ 219,190$ & $\$ 59,415$ \\
Mean log sales & 10.10 & 10.10 & 9.43 \\
& & & \\
Sample size & 38,020 & 15,872 & 7,565 \\
\hline
\end{tabular}

Notes: (1) The sample includes businesses that are classified by the IRS as individidual proprietorships or self-employed persons, partnerships and subchapter S corporporations, have sales of $\$ 500$ or more, and have at least one owner who worked at least 12 weeks and 10 hours per week in the business. (2) All estimates are calculated using sample weights provided by the CBO. 
Table 2

Family Business Background by Race

Characteristics of Business Owners, 1996

\begin{tabular}{|c|c|c|c|}
\hline & All Firms & $\begin{array}{l}\text { White-Owned } \\
\text { Firms }\end{array}$ & $\begin{array}{l}\text { Black-Owned } \\
\text { Firms }\end{array}$ \\
\hline $\begin{array}{l}\text { Percent of owners that had a self-employed } \\
\text { family member prior to starting firm }\end{array}$ & $51.6 \%$ & $53.1 \%$ & $33.6 \%$ \\
\hline $\begin{array}{l}\text { Percent of owners that previously worked in that } \\
\text { family member's business (conditional) }\end{array}$ & $43.6 \%$ & $43.9 \%$ & $37.4 \%$ \\
\hline $\begin{array}{l}\text { Percent of owners that previously worked in a } \\
\text { family member's business (unconditional) }\end{array}$ & $22.5 \%$ & $23.3 \%$ & $12.6 \%$ \\
\hline $\begin{array}{l}\text { Percent of owners that inherited their } \\
\text { businesses }\end{array}$ & $1.6 \%$ & $1.7 \%$ & $1.4 \%$ \\
\hline $\begin{array}{l}\text { Percent of owners that previously worked in a } \\
\text { business with similar goods/services }\end{array}$ & $50.1 \%$ & $50.4 \%$ & $43.1 \%$ \\
\hline $\begin{array}{l}\text { Percent of owners that have previous work } \\
\text { experience in a managerial capacity }\end{array}$ & $55.2 \%$ & $55.6 \%$ & $47.1 \%$ \\
\hline Sample size & 38,020 & 15,872 & 7,565 \\
\hline
\end{tabular}

Note: See notes to Table 1. 
Table 3

Logit and Linear Regressions for Small Business Outcomes

Characteristics of Business Owners, 1996

Specification

(1)

\begin{tabular}{lcccc}
\hline Dependent variable & Closure & Profits & Employer & Ln Sales \\
& & $\$ 10,000+$ & Firm & \\
Black-owned business & 0.1203 & -0.8539 & -0.5793 & -0.4636 \\
& $(0.0738)$ & $(0.0991)$ & $(0.1010)$ & $(0.0554)$ \\
Latino-owned business & -0.0784 & -0.2118 & 0.1407 & 0.0660 \\
& $(0.0685)$ & $(0.0689)$ & $(0.0709)$ & $(0.0490)$ \\
Native American-owned & -0.6684 & 0.2015 & 0.4365 & 0.3991 \\
business & $(0.3149)$ & $(0.2533)$ & $(0.2527)$ & $(0.1879)$ \\
Asian-owned business & -0.2598 & 0.1240 & 0.4432 & 0.4709 \\
& $(0.0822)$ & $(0.0693)$ & $(0.0703)$ & $(0.0539)$ \\
Female-owned business & 0.1403 & -1.0073 & -0.3754 & -0.6941 \\
& $(0.0283)$ & $(0.0315)$ & $(0.0313)$ & $(0.0206)$ \\
High school graduate & -0.1189 & 0.2985 & 0.2723 & 0.1534 \\
& $(0.0481)$ & $(0.0536)$ & $(0.0561)$ & $(0.0351)$ \\
Some college & -0.0571 & 0.3460 & 0.2872 & 0.0570 \\
& $(0.0475)$ & $(0.0531)$ & $(0.0554)$ & $(0.0351)$ \\
College graduate & -0.3143 & 0.5414 & 0.3689 & 0.2397 \\
& $(0.0527)$ & $(0.0563)$ & $(0.0591)$ & $(0.0383)$ \\
Graduate school & -0.8470 & 1.0166 & 1.0049 & 0.6115 \\
& $(0.0608)$ & $(0.0583)$ & $(0.0593)$ & $(0.0404)$ \\
Urban & 0.0934 & 0.2137 & -0.2090 & 0.1008 \\
& $(0.0327)$ & $(0.0329)$ & $(0.0334)$ & $(0.0234)$ \\
Prior work experience in a & 0.3722 & 0.1266 & 0.3125 & 0.2089 \\
managerial capacity & $(0.0309)$ & $(0.0303)$ & $(0.0318)$ & $(0.0217)$ \\
Prior work experience in a & -0.2416 & 0.4894 & 0.2631 & 0.4087 \\
similar business & $(0.0281)$ & $(0.0281)$ & $(0.0294)$ & $(0.0202)$ \\
Have a self-employed & -0.1136 & 0.0539 & -0.0133 & -0.0356 \\
family member & $(0.0314)$ & $(0.0321)$ & $(0.0337)$ & $(0.0227)$ \\
Prior work experience in a & -0.2378 & 0.1541 & 0.3365 & 0.3784 \\
family member's business & $(0.0394)$ & $(0.0376)$ & $(0.0385)$ & $(0.0273)$ \\
Inherited business & -0.5723 & 0.5245 & 1.2222 & 1.3144 \\
& $(0.1345)$ & $(0.1039)$ & $(0.0954)$ & $(0.0800)$ \\
Mean of dependent variable & 0.2280 & 0.2980 & 0.2070 & 10.0725 \\
Sample size & 33,485 & 30,500 & 34,179 & 34,179 \\
\hline & & & & \\
& & &
\end{tabular}

Notes: (1) See notes to Table 1. (2) Logit models are used for Specifications 1-3 and OLS is used for Specification 4. (3) Standard errors are in parenthesis below coefficient estimates. (4) All specifications also include a constant, and dummy variables for marital status of primary owner, region, and work experience of the primary owner. 
Table 4

Logit and Linear Regressions for Small Business Outcomes

Characteristics of Business Owners, 1996

Specification

\begin{tabular}{|c|c|c|c|c|}
\hline & (1) & $(2)$ & (3) & (4) \\
\hline Dependent variable & Closure & $\begin{array}{c}\text { Profits } \\
\$ 10,000+\end{array}$ & $\begin{array}{l}\text { Employer } \\
\text { Firm }\end{array}$ & Ln Sales \\
\hline Black-owned business & $\begin{array}{c}0.0440 \\
(0.0754)\end{array}$ & $\begin{array}{l}-0.8058 \\
(0.1018)\end{array}$ & $\begin{array}{l}-0.4290 \\
(0.1076)\end{array}$ & $\begin{array}{l}-0.3215 \\
(0.0506)\end{array}$ \\
\hline Latino-owned business & $\begin{array}{l}-0.0810 \\
(0.0698)\end{array}$ & $\begin{array}{l}-0.2125 \\
(0.0711)\end{array}$ & $\begin{array}{c}0.1692 \\
(0.0771)\end{array}$ & $\begin{array}{c}0.0735 \\
(0.0447)\end{array}$ \\
\hline $\begin{array}{l}\text { Native American-owned } \\
\text { business }\end{array}$ & $\begin{array}{l}-0.7212 \\
(0.3204)\end{array}$ & $\begin{array}{c}0.1542 \\
(0.2620)\end{array}$ & $\begin{array}{c}0.4246 \\
(0.2767)\end{array}$ & $\begin{array}{c}0.3468 \\
(0.1706)\end{array}$ \\
\hline Asian-owned business & $\begin{array}{l}-0.0519 \\
(0.0848)\end{array}$ & $\begin{array}{l}-0.0843 \\
(0.0719)\end{array}$ & $\begin{array}{l}-0.0999 \\
(0.0783)\end{array}$ & $\begin{array}{c}0.0216 \\
(0.0495)\end{array}$ \\
\hline Female-owned business & $\begin{array}{c}0.0852 \\
(0.0300)\end{array}$ & $\begin{array}{l}-0.9298 \\
(0.0328)\end{array}$ & $\begin{array}{l}-0.3036 \\
(0.0347)\end{array}$ & $\begin{array}{l}-0.5708 \\
(0.0193)\end{array}$ \\
\hline High school graduate & $\begin{array}{l}-0.0371 \\
(0.0495)\end{array}$ & $\begin{array}{c}0.2047 \\
(0.0554)\end{array}$ & $\begin{array}{c}0.1531 \\
(0.0601)\end{array}$ & $\begin{array}{c}0.0324 \\
(0.0325)\end{array}$ \\
\hline Some college & $\begin{array}{c}0.0540 \\
(0.0489)\end{array}$ & $\begin{array}{c}0.3047 \\
(0.0552)\end{array}$ & $\begin{array}{c}0.2426 \\
(0.0596)\end{array}$ & $\begin{array}{c}0.0011 \\
(0.0322)\end{array}$ \\
\hline College graduate & $\begin{array}{l}-0.2460 \\
(0.0548)\end{array}$ & $\begin{array}{c}0.4091 \\
(0.0590)\end{array}$ & $\begin{array}{c}0.2865 \\
(0.0647)\end{array}$ & $\begin{array}{c}0.1441 \\
(0.0355)\end{array}$ \\
\hline Graduate school & $\begin{array}{l}-0.9188 \\
(0.0663)\end{array}$ & $\begin{array}{c}0.7525 \\
(0.0654)\end{array}$ & $\begin{array}{c}1.0214 \\
(0.0700)\end{array}$ & $\begin{array}{c}0.5567 \\
(0.0397)\end{array}$ \\
\hline Urban & $\begin{array}{c}0.0451 \\
(0.0337)\end{array}$ & $\begin{array}{c}0.2920 \\
(0.0342)\end{array}$ & $\begin{array}{l}-0.0879 \\
(0.0362)\end{array}$ & $\begin{array}{c}0.1831 \\
(0.0214)\end{array}$ \\
\hline $\begin{array}{l}\text { Prior work experience in a } \\
\text { managerial capacity }\end{array}$ & $\begin{array}{l}0.4690 \\
(0.0319)\end{array}$ & $\begin{array}{c}0.0359 \\
(0.0316)\end{array}$ & $\begin{array}{l}0.1295 \\
(0.0347)\end{array}$ & $\begin{array}{c}0.0401 \\
(0.0200)\end{array}$ \\
\hline $\begin{array}{l}\text { Prior work experience in a } \\
\text { similar business }\end{array}$ & $\begin{array}{l}-0.2871 \\
(0.0293)\end{array}$ & $\begin{array}{l}0.4605 \\
(0.0294)\end{array}$ & $\begin{array}{c}0.2597 \\
(0.0325)\end{array}$ & $\begin{array}{c}0.4081 \\
(0.0187)\end{array}$ \\
\hline $\begin{array}{l}\text { Have a self-employed } \\
\text { family member }\end{array}$ & $\begin{array}{l}-0.1026 \\
(0.0321)\end{array}$ & $\begin{array}{l}0.0019 \\
(0.0332)\end{array}$ & $\begin{array}{l}-0.0350 \\
(0.0367)\end{array}$ & $\begin{array}{l}-0.0651 \\
(0.0207)\end{array}$ \\
\hline $\begin{array}{l}\text { Prior work experience in a } \\
\text { family member's business }\end{array}$ & $\begin{array}{l}-0.1837 \\
(0.0405)\end{array}$ & $\begin{array}{l}0.1005 \\
(0.0389)\end{array}$ & $\begin{array}{l}0.2098 \\
(0.0422)\end{array}$ & $\begin{array}{c}0.2300 \\
(0.0250)\end{array}$ \\
\hline Inherited business & $\begin{array}{l}-0.4323 \\
(0.1397) \\
\end{array}$ & $\begin{array}{c}0.6465 \\
(0.1140)\end{array}$ & $\begin{array}{l}1.3830 \\
(0.1109)\end{array}$ & $\begin{array}{r}1.3143 \\
(0.0764) \\
\end{array}$ \\
\hline
\end{tabular}


Table 4 (continued)

Logit and Linear Regressions for Small Business Outcomes

Characteristics of Business Owners, 1996

Specification

\begin{tabular}{lcccc} 
Explanatory Variables & $(1)$ & $(2)$ & $(3)$ & $(4)$ \\
\hline Startup capital: & -0.4950 & 0.7202 & 0.9072 & 0.7156 \\
\$5,000-\$24,999 & $(0.0347)$ & $(0.0327)$ & $(0.0360)$ & $(0.0214)$ \\
Startup capital: & -0.7432 & 1.1061 & 1.8769 & 1.4676 \\
\$25,000-\$99,999 & $(0.0512)$ & $(0.0419)$ & $(0.0428)$ & $(0.0291)$ \\
Startup capital: & -1.3036 & 0.8568 & 2.2787 & 2.1520 \\
$\$ 100,000$ or more & $(0.0943)$ & $(0.0598)$ & $(0.0603)$ & $(0.0422)$ \\
Agricultural services & 0.0637 & -0.0532 & -0.9676 & -0.9204 \\
& $(0.0932)$ & $(0.0880)$ & $(0.1021)$ & $(0.0574)$ \\
Mining and construction & 0.2491 & 0.2526 & -0.2151 & -0.2546 \\
& $(0.0546)$ & $(0.0533)$ & $(0.0550)$ & $(0.0350)$ \\
Manufacturing & -0.3550 & 0.1712 & 0.0212 & -0.1055 \\
& $(0.0969)$ & $(0.0795)$ & $(0.0788)$ & $(0.0532)$ \\
Wholesale & 0.0325 & 0.6245 & -0.0038 & 0.6082 \\
& $(0.0841)$ & $(0.0734)$ & $(0.0773)$ & $(0.0518)$ \\
FIRE & -0.3459 & 0.3690 & -1.1322 & -0.4926 \\
& $(0.0620)$ & $(0.0582)$ & $(0.0665)$ & $(0.0367)$ \\
Trans., communications, & 0.3407 & 0.5764 & -0.9290 & -0.3300 \\
and public utilities & $(0.0740)$ & $(0.0705)$ & $(0.0845)$ & $(0.0486)$ \\
Personal services & 0.1107 & -0.2334 & -0.7081 & -0.7430 \\
& $(0.0450)$ & $(0.0459)$ & $(0.0468)$ & $(0.0286)$ \\
Professional services & 0.5529 & 0.3109 & -0.7266 & -0.7021 \\
& $(0.0504)$ & $(0.0524)$ & $(0.0562)$ & $(0.0328)$ \\
Uncoded industry & 0.1124 & -0.4879 & -3.0834 & -0.9842 \\
& $(0.0751)$ & $(0.0876)$ & $(0.2035)$ & $(0.0490)$ \\
Mean of dependent variable & 0.2280 & 0.2975 & 0.2066 & 10.0668 \\
Sample size & 33,116 & 30,271 & 33,701 & 33,701 \\
\hline N & & & & \\
\hline
\end{tabular}

Note: See notes to Table 3. 
Table 5

Decompositions of Black/White Gaps in Small Business Outcomes Characteristics of Business Owners,1996

\section{Specification}

Dependent variable

Black mean

White mean

Black/white gap
(1)

(2)

Closure

0.2696

0.2282

$-0.0414$
Profits

0.1410

0.3004

0.1594
(3)

Employer

0.1121

0.2067

0.0946
(4)

Ln Sales

9.4241

10.0680

0.6439

Contributions from racial

differences in:

\begin{tabular}{lcccc} 
Sex & -0.0032 & 0.0253 & 0.0083 & 0.0689 \\
& $7.7 \%$ & $15.9 \%$ & $8.8 \%$ & $10.7 \%$ \\
Marital status & -0.0037 & 0.0044 & 0.0042 & 0.0166 \\
& $8.9 \%$ & $2.8 \%$ & $4.4 \%$ & $2.6 \%$ \\
Education & -0.0027 & 0.0056 & 0.0023 & 0.0156 \\
& $6.5 \%$ & $3.5 \%$ & $2.4 \%$ & $2.4 \%$ \\
Region & -0.0033 & 0.0032 & -0.0050 & 0.0139 \\
& $8.0 \%$ & $2.0 \%$ & $-5.3 \%$ & $2.2 \%$ \\
Urban & -0.0026 & -0.0060 & 0.0051 & -0.0154 \\
& $6.3 \%$ & $-3.8 \%$ & $5.4 \%$ & $-2.4 \%$ \\
Prior work experience & 0.0011 & -0.0017 & -0.0008 & -0.0011 \\
& $-2.7 \%$ & $-1.1 \%$ & $-0.8 \%$ & $-0.2 \%$ \\
Prior work experience in a & 0.0061 & 0.0016 & 0.0042 & 0.0178 \\
managerial capacity & $-14.7 \%$ & $1.0 \%$ & $4.4 \%$ & $2.8 \%$ \\
Prior work experience in a & -0.0025 & 0.0036 & 0.0017 & 0.0277 \\
similar business & $6.0 \%$ & $2.3 \%$ & $1.8 \%$ & $4.3 \%$ \\
Have a self-employed & -0.0037 & 0.0017 & -0.0004 & -0.0070 \\
family member & $8.9 \%$ & $1.1 \%$ & $-0.4 \%$ & $-1.1 \%$ \\
Prior work experience in a & -0.0048 & 0.0027 & 0.0053 & 0.0412 \\
family member's business & $11.6 \%$ & $1.7 \%$ & $5.6 \%$ & $6.4 \%$ \\
Inherited business & -0.0002 & 0.0005 & 0.0002 & 0.0021 \\
& $0.5 \%$ & $0.3 \%$ & $0.2 \%$ & $0.3 \%$ \\
All included variables & -0.0200 & 0.0409 & 0.0251 & 0.1910 \\
& $48.3 \%$ & $25.7 \%$ & $26.5 \%$ & $29.7 \%$ \\
\hline
\end{tabular}

Notes: (1) The samples and regression specifications are the same as those used in Table 3. (2) Contribution estimates are mean values of the decomposition using 1000 subsamples of whites. See text for more details 
Table 6

Decompositions of Black/White Gaps in Small Business Outcomes

Characteristics of Business Owners,1996

Specification

(1)

Dependent variable
Black mean
White mean
Black/white gap
Contributions from racial
differences in:

Sex

Marital status

Education

Region

Urban

Prior work experience

Prior work experience in a managerial capacity

Prior work experience in a similar business

Have a self-employed family member

Prior work experience in a family member's business

Inherited business

Startup capital

Industry

All included variables

(2)

Closure

0.2692

0.2288

$-0.0404$

Profits

0.1414

0.3003

0.1590

(3)

$\begin{array}{cc}\text { Employer } & \text { Ln Sales } \\ 0.1116 & 9.4221 \\ 0.2065 & 10.0615 \\ 0.0948 & 0.6394\end{array}$

(4)

9.4221

0.6394 
Appendix 1

Multiple Imputation Regressions for Small Business Outcomes

Characteristics of Business Owners, 1996

Specification

(1)

\begin{tabular}{|c|c|c|c|c|}
\hline Dependent variable & Closure & $\begin{array}{c}\text { Profits } \\
\$ 10,000+\end{array}$ & $\begin{array}{l}\text { Employer } \\
\text { Firm }\end{array}$ & Ln Sales \\
\hline Black-owned business & $\begin{array}{c}0.1219 \\
(0.0692)\end{array}$ & $\begin{array}{l}-0.8871 \\
(0.0936)\end{array}$ & $\begin{array}{l}-0.6188 \\
(0.0938)\end{array}$ & $\begin{array}{l}-0.4883 \\
(0.0522)\end{array}$ \\
\hline Latino-owned business & $\begin{array}{l}-0.1089 \\
(0.0647)\end{array}$ & $\begin{array}{l}-0.1619 \\
(0.0641)\end{array}$ & $\begin{array}{c}0.0998 \\
(0.0660)\end{array}$ & $\begin{array}{c}0.0552 \\
(0.0463)\end{array}$ \\
\hline $\begin{array}{l}\text { Native American-owned } \\
\text { business }\end{array}$ & $\begin{array}{l}-0.6992 \\
(0.2990)\end{array}$ & $\begin{array}{c}0.1609 \\
(0.2385)\end{array}$ & $\begin{array}{c}0.3877 \\
(0.2362)\end{array}$ & $\begin{array}{c}0.3944 \\
(0.1783)\end{array}$ \\
\hline Asian-owned business & $\begin{array}{l}-0.2708 \\
(0.0773)\end{array}$ & $\begin{array}{c}0.0940 \\
(0.0650)\end{array}$ & $\begin{array}{c}0.4148 \\
(0.0653)\end{array}$ & $\begin{array}{c}0.4549 \\
(0.0508)\end{array}$ \\
\hline Female-owned business & $\begin{array}{c}0.1140 \\
(0.0271)\end{array}$ & $\begin{array}{l}-0.9820 \\
(0.0298)\end{array}$ & $\begin{array}{l}-0.3814 \\
(0.0294)\end{array}$ & $\begin{array}{l}-0.6942 \\
(0.0197)\end{array}$ \\
\hline High school graduate & $\begin{array}{l}-0.1603 \\
(0.0457)\end{array}$ & $\begin{array}{c}0.3013 \\
(0.0515)\end{array}$ & $\begin{array}{c}0.2326 \\
(0.0536)\end{array}$ & $\begin{array}{c}0.1620 \\
(0.0346)\end{array}$ \\
\hline Some college & $\begin{array}{l}-0.1078 \\
(0.0459)\end{array}$ & $\begin{array}{c}0.3487 \\
(0.0501)\end{array}$ & $\begin{array}{c}0.2501 \\
(0.0522)\end{array}$ & $\begin{array}{c}0.0781 \\
(0.0342)\end{array}$ \\
\hline College graduate & $\begin{array}{l}-0.3546 \\
(0.0509)\end{array}$ & $\begin{array}{c}0.5423 \\
(0.0533)\end{array}$ & $\begin{array}{l}0.3235 \\
(0.0578)\end{array}$ & $\begin{array}{c}0.2428 \\
(0.0373)\end{array}$ \\
\hline Graduate school & $\begin{array}{l}-0.9143 \\
(0.0586)\end{array}$ & $\begin{array}{c}1.0396 \\
(0.0566)\end{array}$ & $\begin{array}{c}0.9431 \\
(0.0582)\end{array}$ & $\begin{array}{c}0.6181 \\
(0.0396)\end{array}$ \\
\hline Urban & $\begin{array}{c}0.0979 \\
(0.0315)\end{array}$ & $\begin{array}{c}0.2261 \\
(0.0313)\end{array}$ & $\begin{array}{l}-0.1733 \\
(0.0316)\end{array}$ & $\begin{array}{c}0.1260 \\
(0.0225)\end{array}$ \\
\hline $\begin{array}{l}\text { Prior work experience in a } \\
\text { managerial capacity }\end{array}$ & $\begin{array}{l}0.3535 \\
(0.0303)\end{array}$ & $\begin{array}{l}0.1173 \\
(0.0296)\end{array}$ & $\begin{array}{l}0.3155 \\
(0.0311)\end{array}$ & $\begin{array}{c}0.2395 \\
(0.0228)\end{array}$ \\
\hline $\begin{array}{l}\text { Prior work experience in a } \\
\text { similar business }\end{array}$ & $\begin{array}{l}-0.2421 \\
(0.0281)\end{array}$ & $\begin{array}{c}0.4819 \\
(0.0273)\end{array}$ & $\begin{array}{c}0.2468 \\
(0.0291)\end{array}$ & $\begin{array}{c}0.3862 \\
(0.0208)\end{array}$ \\
\hline $\begin{array}{l}\text { Have a self-employed } \\
\text { family member }\end{array}$ & $\begin{array}{l}-0.1384 \\
(0.0338)\end{array}$ & $\begin{array}{l}0.0827 \\
(0.0310)\end{array}$ & $\begin{array}{c}0.0064 \\
(0.0334)\end{array}$ & $\begin{array}{l}-0.0138 \\
(0.0231)\end{array}$ \\
\hline $\begin{array}{l}\text { Prior work experience in a } \\
\text { family member's business }\end{array}$ & $\begin{array}{l}-0.2227 \\
(0.0475)\end{array}$ & $\begin{array}{l}0.1478 \\
(0.0365)\end{array}$ & $\begin{array}{l}0.3193 \\
(0.0444)\end{array}$ & $\begin{array}{c}0.3607 \\
(0.0327)\end{array}$ \\
\hline Inherited business & $\begin{array}{l}-0.7252 \\
(0.1290)\end{array}$ & $\begin{array}{c}0.6549 \\
(0.0949)\end{array}$ & $\begin{array}{c}1.1851 \\
(0.0867)\end{array}$ & $\begin{array}{c}1.2058 \\
(0.0736)\end{array}$ \\
\hline Mean of dependent variable & 0.2253 & 0.3009 & 0.2131 & 10.0995 \\
\hline Sample size & 37,156 & 33,804 & 38,020 & 38,020 \\
\hline
\end{tabular}

Note: (1) See notes to Table 3. (2) Missing values for all independent variables are imputed. See text for more details. 
Appendix 2

Means of Selected Variables

Characteristics of Business Owners, 1996

\begin{tabular}{|c|c|c|}
\hline & $\begin{array}{c}\text { White-Owned } \\
\text { Firms }\end{array}$ & $\begin{array}{c}\text { Black-Owned } \\
\text { Firms }\end{array}$ \\
\hline Female-owned business & 0.3268 & 0.4261 \\
\hline Married & 0.8041 & 0.7293 \\
\hline Never married & 0.1398 & 0.1392 \\
\hline High school graduate & 0.2651 & 0.2230 \\
\hline Some college & 0.3123 & 0.3423 \\
\hline College graduate & 0.1962 & 0.1292 \\
\hline Graduate school & 0.1353 & 0.1437 \\
\hline Northeast & 0.0643 & 0.0194 \\
\hline Midatlantic & 0.1469 & 0.1315 \\
\hline East North Central & 0.1666 & 0.1403 \\
\hline West North Central & 0.0847 & 0.0330 \\
\hline South Atlantic & 0.1597 & 0.3259 \\
\hline East South Central & 0.0518 & 0.0792 \\
\hline West South Central & 0.0999 & 0.1443 \\
\hline Mountain & 0.0670 & 0.0163 \\
\hline Urban & 0.7351 & 0.8877 \\
\hline Prior work experience: less than 2 years & 0.0707 & 0.0680 \\
\hline Prior work experience: $2-5$ years & 0.1641 & 0.1500 \\
\hline Prior work experience: $6-9$ years & 0.1507 & 0.1445 \\
\hline Prior work experience: $10-19$ years & 0.2973 & 0.3143 \\
\hline Prior work experience: 20 years or more & 0.2578 & 0.2393 \\
\hline Sample size & 14,282 & 6,831 \\
\hline Startup capital: $\$ 5,000-\$ 25,000$ & 0.2374 & 0.2107 \\
\hline Startup capital: $\$ 25,000-\$ 100,000$ & 0.1095 & 0.0645 \\
\hline Startup capital: $\$ 100,000+$ & 0.0475 & 0.0168 \\
\hline Agricultural services & 0.0269 & 0.0175 \\
\hline Mining and construction & 0.1261 & 0.0718 \\
\hline Manufacturing & 0.0330 & 0.0168 \\
\hline Wholesale & 0.0360 & 0.0112 \\
\hline FIRE & 0.0987 & 0.0609 \\
\hline Trans., communications, and public utilities & 0.0389 & 0.0834 \\
\hline Personal services & 0.2616 & 0.3287 \\
\hline Professional services & 0.1937 & 0.2060 \\
\hline Uncoded industry & 0.0391 & 0.0572 \\
\hline Sample size & 14,068 & 6,743 \\
\hline
\end{tabular}

Notes: (1) The samples are those used in Specifications 3 and 4 of Tables 5 and 6. 